\title{
An in-vitro antibacterial activity of Aloe vera and gentamicin against Escherichia coli and Klebsiella pneumoniae isolates from mastitis milk samples, from Tandojam, Sindh Pakistan
}

Ubaidullah Jokhio $^{1}$, Rehana Shahnawaz Buriro ${ }^{1 *}$, Shamsuddin Bughio ${ }^{1}$, Saeed Ahmed Soomro ${ }^{3}$, Muhammad Bilawal Arain ${ }^{1}$, Ali Gul Soomro ${ }^{1}$, Faiza Habib ${ }^{3}$, Zainab Lanjar ${ }^{1}$, Wali Khan ${ }^{1}$ and Faisal Khan ${ }^{1}$

1. Department of Veterinary Pharmacology, Sindh Agriculture University, Tando Jam, Pakistan

2. Department of Animal Physiology and Biochemistry, Sindh Agriculture University, Tando Jam, Pakistan

3. Department of Livestock and Dairy Development, Quetta, Balochistan, Pakistan

*Corresponding author's email: rsburiro@hotmail.com

Citation

Ubaidullah Jokhio, Rehana Shahnawaz Buriro, Shamsuddin Bughio, Saeed Ahmed Soomro, Muhammad Bilawal Arain, Ali Gul Soomro, Faiza Habib, Zainab Lanjar, Wali Khan and Faisal Khan. An in-vitro antibacterial activity of Aloe vera and gentamicin against Escherichia coli and Klebsiella pneumoniae isolates from mastitis milk samples, from Tandojam, Sindh Pakistan. Pure and Applied Biology. Vol. 11, Issue 2, pp411-420.

http://dx.doi.org/10.19045/bspab.2022.110041

Received: 05/02/2021 Revised: 23/04/2021

Accepted: 28/07/2021

Online First: 26/08/2021

\section{Abstract}

The current study was conducted to examine the in vitro antibacterial activity of pure Aloe vera extract and compared with commonly used antibiotic, Gentamicin against Escherichia coli and Klebsiella pneumonia isolated from mastitis milk. For this purpose, 50 milk samples were collected from dairy farms in the vicinity of Tandojam and processed the samples for culture, identification, and Minimum inhibitory concentration of pure Aloe vera extract and gentamicin in the laboratory of department of Veterinary Pharmacology, Sindh Agriculture University Tandojam, to record the MIC against isolated organisms at different concentrations i-e 40, 20, 10, $5,2.5,1.25,0.625,0.312,0.156,0.081$ and $0.039 \mu 1$. The MIC of the isolates was determined by the turbidity and translucency of the cultured medium Results of present study revealed that out of 50 milk samples, $35(70 \%)$ and $15(30 \%)$ were found positive for E. coli and K. pneumonia, respectively. It was found that $E$. coli stopped growth at $10 \mu 1$ of pure Aloe vera and $1.25 \mu 1$ of Gentamicin. Whereas K. pneumoniae failed to grow at $2.5 \mu \mathrm{l}$ of pure Aloe vera, but it was found highly susceptible for gentamicin and stopped growth at lowest conc: i-e $0.03 \mu$. The comparative results revealed that the concentrations of Aloe vera used in this study were not as effective as that of commercial product, but Aloe vera stopped the growth of isolated organisms at certain level as that of gentamicin. Therefore, due to emergence of resistance towards antibiotics, Aloe vera can be used as a substitute of antibiotics.

Keywords: Aloe vera; Antibacterial activity; Escherichia coli; Gentamicin; Mastitis milk 


\section{Introduction}

Dairy animals affected from different types of diseases among them bovine mastitis is a main problem of dairy sector generating monetary losses, decrease milk production, need costly medicine and if remedy is unsuccessful then the animals are culled. For consuming and processing, it has been found that milk from mastitis animals has lot of organism which lowered the quality of milk products and affected the health of consumer [1].

Mastitis in buffalo is defined as response of parenchyma cells of mammary gland towards the traumatic injury and infection, which is characterized by five signs, i.e, swelling, redness, loss of function, pain and hotness [2]. In buffalo, vast numbers of microorganisms have been reported to cause mastitis and among those major etiological agents are bacteria which include either gram positive or gram-negative. Mastitis has been classified as contagious and environmental based on causative organisms. Environmental mastitis is caused by gram negative bacteria which include Klebsiella pneumoniae, Klebsiella aerogenosa, Escherichia coli, Citrobacter spp., Pseudomonas spp and Proteus spp. [3].

Bovine mastitis is mostly treated with antimicrobial agents through intra-mammary infusion, as well as some systemic drugs are also used. Commonly different antibiotics are used in dairy animals to prevent or control bacterial infections among those Gentamicin is mostly used to treat mastitis This antibacterial belongs to aminoglycoside class and has bactericidal as well as bacteriostatic activity and clinically effective in treatment of gram-negative infections [4].

It has been observed that gram negative organisms such as Klebsiella pneumoniae, Klebsiella aerogenosa and Escherichia coli are susceptible towards the Gentamicin [5]. It has been reported that this antibiotic has broad activity against gram negative bacteria i.e E. coli, Klebsiella pneumoniae, Proteus spp and Enterobacter aerogene [6]. It has been examined that gram-negative pathogens were more sensitive towards the gentamicin [7].

Aloe vera generally known as Aloe, has more than 300 species throughout the world. It is endless succulent xerophyte plant which has developed water storage cells in the leaves to live in dry area and belongs to the Liliaceae family. The internal part of leaf is a clear, soft, moist and slippery tissue that consist of large thin-walled parenchyma cells in which water is held in the form of a viscous mucilage in the form of gel [8]. Due to its curative and therapeutic properties, it has been used since ages and so far, more than 75 active ingredients have been identified from inner gel. It has several therapeutic properties and used as an anti-allergic, healing activity, anti-carcinogenic, immuno- modulatory effect as well as having antifungal, antibacterial, antiviral and ant-inflammatory activity [9]. It has been evaluated that Aloe vera extract possesses medicinal activity including antioxidant, triggering of hematopoiesis, anti-neoplastic effect, promotion of radiation damage repair, antidiabetic and antimicrobial, due to presence of polysaccharides, found in parenchymal tissue of inner leaf [10].

So far, very little work has been done on the in vitro antibacterial activity of Aloe vera against Escherichia coli and Klebsiella pneumoniae and its comparison with Gentamicin through MIC. Therefore, present study has been designed to check the antibacterial activity of Aloe vera and compared with Gentamicin against E. coli and Klebsiella pneumoniae.

Materials and Methods

Sampling and bacteriological isolation and identification

A total of 50 clinical mastitis milk samples of buffaloes were collected under aseptic condition, in bijous bottle from the dairy 
farms of the vicinity of Tandojam and were brought to post graduate research laboratory of the department of Veterinary Pharmacology, Sindh Agriculture University Tandojam.

\section{Preparation of media for culture}

The different media were used to culture the bacteria to isolate the bacterial species such as E. coli and Klebsiela pneumoniae, isolated from mastitis milk. Those included Nutrient, Blood and MacConkey's agar.

Nutrient agar, MacConkey agar, Muller Hinton Broth are prepared according to manufacturing company.

\section{Culture characteristics of bacteria}

Samples were cultured onto nutrient agar, for primary culture. Purification of the isolates was done by subculturing onto blood agar and MacConkey's agar then incubated at 37 ${ }^{\circ} \mathrm{C}$ for 24 hrs. After 24 hours, colonies from nutrient and blood agar were picked up by sterilized wire loop for subculture and the process of sub-culturing was continued till pure colonies growth was obtained. Identification of organisms was performed by cultural, morphological and biochemical characteristics. Grams' staining was done to check the staining reaction of the isolates. After that, pure colonies were transferred to sterile nutrient agar slant, which were then incubated for 24 hours and refrigerated at 4 ${ }^{0} \mathrm{C}$ as stock culture.

\section{Isolation and identification of pathogens} Gram staining characteristic of bacteria

Smears was prepared form the pure isolated colonies, stained with grams stain and the characteristics of the organisms were recorded as either gram-negative or grampositive.

\section{Biochemical test for the identification of isolated organisms}

Bacterial organism was further confirmed by following biochemical tests.

\section{Catalase test}

The catalase test was used to differentiate catalase positive bacteria from catalase negative bacteria because enzyme catalase is produced by bacteria that respire using oxygen and protects them from the toxic byproducts of oxygen metabolism. Such as $E$. coli and Pseudomonas

\section{Oxidase test}

The test was conducted to examine the ability of bacterial organisms to produce the oxidase, an enzyme. A positive reaction was indicated by an intensive blue coloration of the paper within 10 seconds. The oxidase reagent was prepared by adding Tetraphenylene diamine dihydrochloride (dye) 0.1 gram and ascorbic acid 0.01 gram in $10 \mathrm{ml}$ distilled water.

\section{Extraction of gel from Aloe vera leaves}

The Aloe vera plant leaves were collected from the local plant nursery, of Tandojam. The plant leaves were cleaned with $70 \%$ alcohol. The leaves were incised, and gel was separated with the help of sterile knife. Further, the gel was blended to make it homogenous and filtered with muslin cloth and sterilized by using autoclave at $121^{\circ} \mathrm{C}$ for 15 minutes at $15 \mathrm{lbs}$ pressure, then sterilized stock solution (100\% concentration) was used as an antibacterial activity.

\section{Determination of MIC (Minimum} Inhibitory Concentration)

Aloe vera and Gentamicin were used during this study, to evaluate the susceptibility of the organisms. The susceptibility test was done by micro broth dilution method on MullerHinton (MH) medium. 1:1000 dilution was prepared for MIC. For this, $6 \mu 1$ of bacteria cultured Tryptic Soy Broth (TSB) were added into $6 \mathrm{ml}$ of Muller Hinton (MH) medium, 96 well plates were used to determine minimum inhibitory concentration (MIC) of Aloe Vera and Gentamicin against Escherichia coli and Klebsiella pneumoniae. In $1^{\text {st }}$ well, $100 \mu l$ of the $(\mathrm{MH})$ medium were

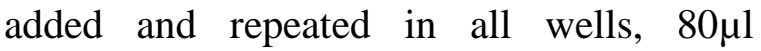
concentration of bacterial culture was added in $1^{\text {st }}$ and $2^{\text {nd }}$ well and $20 \mu 1$ of Aloe vera were added in $2^{\text {nd }}$ well then $100 \mu$ l concentration 
of Aloe vera were taken from $2^{\text {nd }}$ well and added in $3^{\text {rd }}$ well, this procedure was followed up to $12^{\text {th }}$ well respectively. For Gentamicin, concentration of $15 \mathrm{mg} / 15 \mathrm{ml}$ (stock solution) was used against the isolates and same procedure as mentioned above was followed for Gentamicin. The MIC plates were incubated at $37^{\circ} \mathrm{C}$ overnights. After that, the break points were recorded by observing the transparency and turbidity of the cultured medium in order to determine the minimum inhibitory activity of Aloe vera and Gentamicin. [11]. The obtained data was compared with control and the concentrations where the isolated organisms stopped to grow with Aloe vera and Gentamicin.

\section{Data analysis}

The break points, where the bacteria stopped to grow were recorded as MIC for antibiotic as well as pure Aloe vera extract by turbidity or non-turbidity of culture.

\section{Results}

The percentage prevalence of bacterial organisms isolated from mastitic milk

A total 50 milk samples were examined, and all were recorded positive. Out of those 35 and 15 were found positive for Escherichia coli and Klebsiella pneumoniae respectively (Table 1). All organisms were identified on their morphological, cultural characteristics and staining reactions.

Susceptibility of isolated bacteria at different concentrations of pure Aloe vera extract

The concentrations of $40 \mu 1,20 \mu 1,10 \mu 1,5 \mu 1$, $2.5 \mu 1,1.25 \mu 1,0.62 \mu 1,0.31 \mu 1,0.15 \mu 1,0.07 \mu 1$, $0.03 \mu 1$, and $0.01 / \mu 1$ of pure Aloe vera extract were used to check the susceptibility of isolated organisms. Escherichia coli presented break points at $40 \mu \mathrm{l}, 20 \mu \mathrm{l}$ and $10 \mu \mathrm{l}$ concentrations while at lower concentration it showed resistance, which was observed by turbidity of the medium. Whereas Klebsiella pneumoniae displayed break points at $40 \mu \mathrm{l}$,
$20 \mu 1,10 \mu 1,5 \mu 1$ and $2.5 \mu 1$ concentrations while at lower concentrations the organism showed resistance by growth at that concentration (Table 2).

Susceptibility of isolated bacteria at different concentrations of Gentamicin

The concentrations of $40 \mu 1,20 \mu 1,10 \mu 1,5 \mu 1$, $2.5 \mu 1,1.25 \mu 1,0.62 \mu 1,0.31 \mu 1,0.15 \mu 1,0.07 \mu 1$, $0.03 \mu 1$ and $0.01 / \mu 1$ of Gentamicin were used to determine the susceptibility of Escherichia coli and Klebsiella pneumoniae. Escherichia coli was recorded, susceptible at $40 \mu 1,20 \mu 1$, $10 \mu \mathrm{l}, 5 \mu \mathrm{l}, 2.5 \mu \mathrm{l}$ and $1.25 \mu \mathrm{g} / \mu \mathrm{l}$ and this susceptibility was observed by clear/translucence appearance of the medium. While at lower concentrations, the isolated organism showed resistance, Whereas Klebsiella pneumoniae showed susceptibility even at lowest concentration of the gentamicin i-e $0.03 / \mu 1$ (Table 3 ) which was observed by turbidity of the medium in 96 well plates.

Comparison of antibacterial activity of Aloe vera and Gentamicin against isolated bacteria

The concentrations of $40 \mu 1,20 \mu 1,10 \mu 1,5 \mu 1$, $2.5 \mu 1,1.25 \mu 1,0.62 \mu 1,0.31 \mu 1,0.15 \mu 1,0.07 \mu 1$, $0.03 \mu 1,0.01 \mu 1$ of Aloe vera extract as well as Gentamicin were used to compare the susceptibility of isolated bacterial organisms. The E. coli exhibited susceptibility at $40 \mu 1$, $20 \mu \mathrm{l}$ and $10 \mu \mathrm{l}$ of pure Aloe vera extract while it showed susceptibility to Gentamicin at $40 \mu 1,20 \mu 1,10 \mu 1,5 \mu 1,2.5 \mu 1,1.25 \mu 1$. whereas, The Klebsiella pneumoniae was found susceptible at $40 \mu 1,20 \mu 1,10 \mu 1,5 \mu 1$ and $2.5 \mu 1$ concentrations and $40 \mu 1,20 \mu 1,10 \mu 1,5 \mu 1$, $2.5 \mu 1,1.25 \mu 1,0.62 \mu 1,0.3 \mu 1,0.15 \mu 1,0.07 \mu 1$, $0.03 \mu \mathrm{l}$ of Aloe vera extract and Gentamicin respectively (Table 4).

Hence, it is proved from this study that pure Aloe vera can be used as an alternate of antibiotics as it stopped the growth of isolated bacterial organisms at certain levels. 
Table 1. The percentage prevalence of bacterial organisms isolated from mastitic milk samples

\begin{tabular}{|c|c|c|c|}
\hline Bacterial species & $\begin{array}{c}\text { Total No. of mastitic } \\
\text { milk samples }\end{array}$ & No. of positive milk samples & Percentage \\
\hline Escherichia coli & \multirow{2}{*}{50} & 35 & $70 \%$ \\
\cline { 1 - 2 } Klebsiella pneumonia & & 15 & $30 \%$ \\
\hline
\end{tabular}

Table 2. Susceptibility of isolated Escherichia coli and Klebsiella pneumoniae at different concentrations of Pure Aloe vera extract

\begin{tabular}{|c|c|c|c|c|c|c|c|c|c|c|c|c|}
\hline $\begin{array}{c}\text { Bacterial } \\
\text { species }\end{array}$ & $\begin{array}{c}\text { Con } \\
\text { trol }\end{array}$ & $\begin{array}{c}40 \\
\mu \mathrm{l}\end{array}$ & $\begin{array}{c}20 \\
\mu \mathrm{l}\end{array}$ & $\begin{array}{c}10 \\
\mu \mathrm{l}\end{array}$ & $\begin{array}{c}5 \\
\mu \mathrm{l}\end{array}$ & $2.5 \mu \mathrm{l}$ & $\mathbf{1 . 2 5 \mu \mathrm { l }}$ & $\mathbf{0 . 6 2 \mu \mathrm { l }}$ & $\begin{array}{c}\mathbf{0 . 3 1} \\
\mu \mathrm{l}\end{array}$ & $\begin{array}{c}0.15 \\
\mu \mathrm{l}\end{array}$ & $\begin{array}{c}\mathbf{0 . 0 7} \\
\mu \mathrm{l}\end{array}$ & $\begin{array}{c}\mathbf{0 . 0 3} \\
\mu \mathrm{l}\end{array}$ \\
\hline $\begin{array}{c}\text { Escherichia coli } \\
\begin{array}{c}\text { Klebsiella } \\
\text { pneumoniae }\end{array}\end{array}$ & + & - & - & - & + & + & + & + & + & + & + & + \\
\hline
\end{tabular}

- = susceptibility

$+=$ Resistance

Table 3. Susceptibility of isolated Escherichia coli and Klebsiella pneumoniae against various concentrations of Gentamicin

\begin{tabular}{|c|c|c|c|c|c|c|c|c|c|c|c|c|}
\hline $\begin{array}{l}\text { Bacterial } \\
\text { species }\end{array}$ & Control & $\begin{array}{l}40 \\
\mu l\end{array}$ & $\begin{array}{l}20 \\
\mu l\end{array}$ & $\begin{array}{l}10 \\
\mu l\end{array}$ & $\begin{array}{l}5 \\
\mu l\end{array}$ & $\begin{array}{c}2.5 \\
\mu l\end{array}$ & $\begin{array}{c}1.25 \\
\mu l\end{array}$ & $\begin{array}{c}0.625 \\
\mu l\end{array}$ & $\begin{array}{c}0.3125 \\
\mu l\end{array}$ & $\begin{array}{c}0.15625 \\
\mu l\end{array}$ & $\begin{array}{c}0.078125 \\
\mu l\end{array}$ & $\begin{array}{c}0.0390625 \\
\mu \mathrm{l}\end{array}$ \\
\hline $\begin{array}{c}\text { Escherichia } \\
\text { coli }\end{array}$ & + & - & - & - & - & - & - & + & + & + & + & + \\
\hline $\begin{array}{c}\text { Klebsiella } \\
\text { pneumonia }\end{array}$ & + & - & - & - & - & - & - & - & - & - & - & - \\
\hline
\end{tabular}

- = susceptibility

$+\quad=$ Resistance

Table 4. Comparative Susceptibility of Escherichia coli and Klebsiella pneumonia at various concentrations of Gentamicin and pure Aloe vera extract

\begin{tabular}{|c|c|c|c|c|c|}
\hline \multicolumn{2}{|c|}{ CONCENTRATION } & \multicolumn{2}{c|}{ Escherichia coli } & \multicolumn{2}{c|}{ Klebsiella pneumonia } \\
\hline & Control & Aloe vera & Gentamicin & Aloe vera & Gentamicin \\
\hline $40 \mu 1$ & + & - & - & - & - \\
\hline $20 \mu 1$ & + & - & - & - & - \\
\hline $10 \mu 1$ & + & - & - & - & - \\
\hline $5 \mu 1$ & + & + & - & - & - \\
\hline $2.5 \mu 1$ & + & + & - & - & - \\
\hline $1.25 \mu 1$ & + & + & - & + & - \\
\hline $0.62 \mu 1$ & + & + & + & + & - \\
\hline $0.31 \mu 1$ & + & + & + & + & - \\
\hline $0.15 \mu 1$ & + & + & + & + & - \\
\hline $0.07 \mu 1$ & + & + & + & + & - \\
\hline $0.03 \mu 1$ & + & + & + & + & + \\
\hline $0.01 \mu 1$ & + & + & + & + & \\
\hline
\end{tabular}

- = Susceptibility

$+=$ Resistance 


\section{Discussion \\ The percentage prevalence of bacterial organisms isolated from mastitis milk}

During this study, fifty clinical mastitic milk samples of buffaloes were collected under aseptic condition. Out of 50 samples, 35 and 15 were found positive for Escherichia coli and Klebsiella pneumoniae respectively, which are most prevalent bacteria found in mastitis milk of buffalo. It is reported in this study that Escherichia coli and Klebsiella pneumoniae were having prevalent percentage as $70 \%$ and $30 \%$.

Present findings are in line with [3], who reported that different microorganisms are cause of buffalo mastitis and among them Escherichia coli was most prevalent followed by Klebsiella pneumonia with the $40 \%$ and $25 \%$ respectively. Somewhere resent findings are agreement with [12] who reported different type of bacteria including both g+ve and g-ve, and among gram negative pathogens, Escherichia coli and Klebsiella pneumoniae were most prevalent having 55 and $19 \%$ prevalence, respectively. Similar type of study reported that environmental mastitis in buffalo is mostly caused by gram negative bacteria including Klebsiella pneumoniae, Pseudomonas aerogensa Escherichia coli, Serratia marcescens, Citrobacter spp. Pseudomonas spp. and other gram-negative bacteria include Proteus, and among all organisms E. coli was highly prevalent with 49\% [13]. Present findings are in line with [14] who reported that, among g-ve bacteria, major prevalent bovine mastitis pathogens were Escherichia coli and Klebsiella pneumonia having 32 and $14 \%$ prevalence. Therefore, in the light of previous studies, it has been confirmed that Escherichia coli and Klebsiella pneumoniae are highly prevalent in bovine mastitis milk samples in this study.

\section{Susceptibility of isolated organisms to different concentrations of Aloe vera extract}

In present study, various concentrations of Aloe vera extract i-e from $0.039 \mu \mathrm{l}$ to $40 \mu \mathrm{l}$ were used to check the susceptibility of isolated organism. Escherichia coli and Klebsiella pneumoniae showed break points at $10 \mu 1$ and $2.5 \mu 1$, respectively.

Present results are comparable with [15] who reported that Aloe vera possessed the antibacterial activity against gram negative bacterial organisms i,e, Escherichia coli. [16] also observed that growth of Escherichia coli and Klebsiella pneumoniae was inhibited in the medium which is containing Aloe vera. Another study was conducted to examine the antibacterial activity of Aloe vera extract against E. coli as well as Klebsiella pneumoniae, which showed that it has moderate to high activity against both organisms mentioned earlier [17]. Present results are in accordance with [18], who suggested that Aloe vera extract has also exhibited antimicrobial effect against gramnegative bacteria such as Pseudomonas aeruginosa, E. coli and Klebsiella pneumonia at 10 and $5 \mu 1$ respectively but disc diffusion method was used. Similarly, kind of study, was conducted by [2], who reported that Aloe vera possesses the antibacterial activity against gram negative organisms including, E. coli and Klebsiella pneumoniae.[8] also reported that Aloe vera possessed strong antibacterial effect. Present results are in accordance with [15] who reported that Aloe vera has potent antibacterial activity against different gram-negative organisms including Escherichia coli and Klebsiella pneumonia and (MIC) values ranged from 31.25 to 4000 and 62.5 to $8000 \mu \mathrm{g} / \mathrm{ml}$. Similar type of study was conducted to evaluate the antibacterial activity of Aloe vera and it was observed from result that gram-negative bacteria are found susceptible, to Aloe vera such as Escherichia coli and Klebsiella pneumoniae 
[9]. Present results are in line with previous study by [19] who reported that Aloe vera possessed inhibitory activity against Salmonella typhi, Klebsiella pneumoniae, Escherichia coli, Bacillus subtilius and Pseudomonas epidermidis. Furthermore, it has potent antibacterial effect against gram negative organisms, and this activity is principally due to presence of biological elements such as Aloin and anthraquinone, which block the bacterial protein synthesis. Current findings are comparable with previous studies $[9,20]$ who used Aloe liquid and found its efficacy as an antibacterial agent against wide range of gram positive and gram-negative bacteria. The antimicrobial agents of Aloe vera gel was reported to either effectively kill or greatly reduce growth of Staphylococcus aureus, Klebsiella pneumoniae, Streptococcus pyogenes, Pseudomonas aeruginosa, Escherichia coli, Propionibacterium acne, Helicobacter pylori and Salmonella typhi.

Current results are in accordance with [17, 18] who found that Aloe vera possessed antibacterial activity against Salmonella typhi, Klebsiella pneumoniae, Escherichia coli, Bacillus subtilius, and Pseudomonas epidermidis. It has direct antimicrobial activity due to presence of various components in Aloe vera such as saponins, anthraquinones and pyrocatechol [21]. The antibacterial activity of Aloe vera is due to presence of Anthraquinone which works as protein synthesis inhibitor like tetracycline and which acts by retarding the synthesis of bacterial protein through blocking active site of ribosomes [22, 23].

Susceptibility of isolated organisms against different concentration of Gentamicin

Gentamicin is an aminoglycoside with wide spectrum antibacterial activity and has been used for diverse decades for therapy of severe infections caused by gram negative bacteria such as E. coli, Enterobacter spp. as well as g+ve including Staphylococcus spp. and Streptococcus spp. [24]. Its mode action revealed that it inhibits the bacterial protein synthesis through binding to 30 s ribosomes, and effective in severe infections caused via gram negative organisms [25]. It has been stated that gram negative organisms such as E. coli, Klebsiella pneumoniae and Pseudomonas aeruginosa were found susceptible to Gentamicin [26]. It has extended spectrum towards the Klebsiella pneumoniae, Klebsiella aerogens, Proteus spp and E. coli [18]. It has been determined that gram negative bacteria do not resistant towards it [7].

In present study various concentrations of Gentamicin i-e from $0.039 \mu \mathrm{g} / \mu \mathrm{l}$ to $40 \mu \mathrm{g} / \mu \mathrm{l}$ were used to check the susceptibility of isolated organism. MIC at which growth of Escherichia coli and Klebsiella pneumoniae inhibited was $1.25 \mu \mathrm{g} / \mu \mathrm{l}$ and $0.0390625 \mu \mathrm{g} / \mu \mathrm{l}$ respectively. In current study it was found that Escherichia coli was less susceptible as compared to the Klebsiella pneumoniae which is inhibited even at lowest concentration i-e, $0.039 \mu \mathrm{g} / \mu \mathrm{l}$ and hence considered as MIC for Klebsiella pneumoniae. In current result, MIC of Escherichia coli was recorded as $1.25 \mu \mathrm{g} / \mu \mathrm{l}$. The present results showed agreement with the previous finding in which it has been reported that the Escherichia coli showed susceptibility against Gentamicin and its MIC ranges between 0.25-4.0 $\mu \mathrm{g} / \mathrm{ml}[11,27$, 28]. In another study the MIC of Escherichia coli was determined, and it was found that Escherichia coli was susceptible at $0.5 \mathrm{mg} / \mathrm{L}$. Present result are comparable with [18] who reported that MIC at which growth of Escherichia coli was inhibited ranged between 0.25 to $0.5 \mu \mathrm{g} / \mathrm{ml}$, Whereas, MIC for Klebsiella pneumoniae was determined as $0.039 \mu \mathrm{g} / \mu \mathrm{l}$. Present result are in line with [28] who reported that Klebsiella pneumoniae was susceptible against Gentamicin and MIC at which growth 
inhibited ranged between $0.25-4 \mathrm{mg} / \mathrm{l}$. Present findings are comparable with [5] who reported that gram negative organisms such as E. coli, Klebsiella pneumoniae and Pseudomonas aeruginosa, were found susceptible. Current results are comparable with previous study of [18] who suggested that the extended spectrum effect of antibacterial towards the Klebsiella pneumoniae, Klebsiella aerogens, Proteus spp and E. coli. Present findings can be supported with $[8,29]$. Who determined that gram negative bacteria do resistant towards gentamicin and E. coli Present results are comparable with $[28,30]$ who found that gram negative bacteria i.e., E. coli and Klebsiella pneumoniae are susceptible. Another study conducted by [31] reported that different bacterial species are susceptible toward Gentamicin such as E. coli, Salmonella spp. Klebsiella spp. Pseudomonas spp. Clostridium spp. and Neisseria gonorrhea.

The results of present study are an indication that Aloe vera can be used as substitute of antibiotics due to its antibacterial effect and it helps to prevent bacterial resistance in the environment.

\section{Conclusion}

Isolated E. coli was found MIC susceptible at $10 \mu \mathrm{l}$ of Aloe vera. Isolated K. pneumoniae was recorded MIC susceptible at $2.5 \mu \mathrm{l}$ of Aloe vera. Both isolated organisms showed MIC against Gentamicin at $1.25 \mu \mathrm{g} / \mu \mathrm{l}$ and $0.039062 \mu \mathrm{g} / \mu \mathrm{l}$.

\section{Authors' contributions}

Conceived and designed the experiments: $\mathrm{U}$ Jokhio, RS Buriro, S Bughio \& SA Somroo, Performed the experiments: U Jokhio, AG Soomro, Z Lanjar \& F Khan, Analyzed the data: U Jokhio, F Habib \& W Khan, contributed materials/ analysis/ tools: RS Buriro, S Bughio, Wrote the paper: MB Arain.

\section{Acknowledgement}

The authors are thankful to the team of Molecular Parasitology Laboratory, Sindh Agriculture University, Tando Jam for providing Laboratory facilities, which are essential for successful completion of the present research work.

\section{References}

1. Bilal MQ, Iqbal MU, Mohammad G, Avais M \& Sajid MS (2004). Factors affecting the prevalence of clinical mastitis in buffaloes around Faisalabad district (Pakistan). Int J of Agric Biol 6: 185-187.

2. Fitzgerald KT, Bronstein AC \& Newquist KL (2013). Marijuana poisoning. Topics in Comp Ani Med 28(1): 8-12.

3. Johnson M, Renisheya JM, Nancy BS, Laju RS, Aruriya G \& Renola JT (2012). Antimicrobial and Antifungal activity of Aloe vera Gel Extract. J of Int Biom and Adv Res 3: 184-187.

4. Brown LB, Krysiak R, Kamanga G, Mapanje C, Kanyamula H, Band B \& Hosseinipour MC (2010). Neisseria gonorrhoeae antimicrobial susceptibility in Lilongwe, Malawi, 2007. Sex Trans Dis 37(3): 169-172.

5. Thiruppathi S, Ramasubramanian V, Sivakumar T \& Thirumalaiaras V (2010). Antimicrobial activity of Aloe vera (L.) Burm. f. against pathogenic microorganisms. J Biosci Res 1(4): 251258.

6. Salmon SA (2002). Use of antimicrobial susceptibility data to assist in determining the best therapy for clinical mastitis. In Proceedings NMC 41st Annual Meeting, Orlando, Florida, USA.

7. Dhakal IP, Dhakal P, Koshihara $\mathrm{T} \&$ Nagahata H (2007). Epidemiological and bacteriological survey of buffalo mastitis in Nepal. J of Vet Med Sci 69(12): 12411245.

8. Ni Y \& Tizard IR (2004). Analytical methodology: the gel-analysis of aloe 
pulp and its derivatives. In Aloes. The Genus Aloe; Reynolds, T, Ed.; CRC Press: Boca Raton, 111-126.

9. Oliveira DDM, Macedo AAM \& Silva ARA (2012). August. Antioxidant activity in vitro, the ethanol extract of the Gel of ALOE VERA. Electronic Conference Management System, VII CONNEPI - Congr North Northeast of Rese and Inno.

10. Lawless J \& Allan J (2000). The clinical composition of Aloe Vera. In: Aloe Vera: Natural Wonder Cure. London: Thorsons Publishing Ltd 161-171.

11. Andrews JM, (2001). Determination of minimum inhibitory concentrations. $J$ of antim Chem 48(1): 5-16.

12. Sumathi BR, Veeregowda BM \& Amitha RG (2008). Prevalence and antibiogram profile of bacterial isolates from clinical bovine mastitis. Vet World 1(8): 237-238.

13. Kametani S, Kojima-Yuasa A, Kikuzaki H, Kennedy DO, Honzawa M \& MatsuiYuasa I (2007). Chemical constituents of cape aloe and their synergistic growthinhibiting effect on Ehrlich ascites tumor cells. Bios Biotech \& Biochem 71(5): 1220-1229.

14. Reynolds T \& Dweck AC (1999). Aloe vera leaf gel: a review update. J of Ethnop 68(1-3): 3-37.

15. Irshad S, Butt M \& Younus H (2011). Invitro antibacterial activity of Aloe barbadensis Miller (Aloe vera). Int Res $J$ of Pharmaceut 1(2): 59-64.

16. Dhingra D, Lamba D, Kumar R, Nath P \& Gauttam S (2014). Antihyperlipidemic activity of Aloe succotrina in rats: possibly mediated by inhibition of HMGCoA reductase. Pharmacol 63(2): 143147.

17. Katholm J, Bennedsgaard TW, Koskinen MT \& Rattenborg E (2012). Quality of bulk tank milk samples from Danish dairy herds based on real-time polymerase chain reaction identification of mastitis pathogens. $J$ of Dairy Sci 95(10): 5702-5708.

18. Salmon SA \& Watts JL (2000). Minimum inhibitory concentration determinations for various antimicrobial agents against 1570 bacterial isolates from turkey poults. Avian Dis 1: 85-98.

19. Hathorn E, Dhasmana D, Duley L \& Ross J (2014). The effectiveness of gentamicin in the treatment of Neisseria gonorrhoeae: a systematic review. Sys Rev 3: 104-107.

20. Pug N, Ross SA, ElSohly MA \& Pasco DS (2001). Characterization of Aloeride, a new high-molecular-weight polysaccharide from Aloe vera with potent immunostimulatory activity. $J$ Agric and Food Chem 49(2): 1030-1034.

21. Jones GM (2006). Understanding the basics of mastitis. Virginia Cooperative Extension. Publication No. 404-233. Virginia State University, USA, 1-7. 2830.

22. Fani M, \& Kohanteb J (2012). Inhibitory activity of Aloe vera gel on some clinically isolated cariogenic and periodontopathic bacteria. J of Oral Sci 54(1): 15-21.

23. Kedarnath KK, Chimkod VB \& Patil CS (2013). Antimicrobial activity of Aloe vera leaf extract. Int J Biol Pharm Tech 4(4): 286-290.

24. Bassetti M, Merelli M, Temperoni C \& Astilean A (2013). New antibiotics for bad bugs: where are we. Annals of Clin Microbiol and Antimicrob 12(1): 22-28.

25. Geary U, Lopez-Villalobos N, Begley N, McCoy F, O'brien B, O'grady L \& Shalloo L (2012). Estimating the effect of mastitis on the profitability of Irish dairy farms. J of Dairy Sci 95(7): 3662-3673.

26. Verbeke J, Piepers S, Supre K \& Vliegher SD (2014). Pathogen specific incidence rate of clinical mastitis in Flemish dairy herds, severity, and association with herdhygiene. J Dairy Sci 97: 6926-6934. 
27. Riekerink RO, Barkema H, Scholl DT, Poole DE \& Kelton AC (2010). Management practices associated with the bulk-milk prevalence of Staphylococcus aureus in Canadian dairy farms. Prev Vete Med 97: 20-28

28. Chauhan PM, Thumar HK, Bhagat A, Sharma VK, Chauhan HC \& Patel MR (2016). Comparative efficacy of antibiotic sensitivity tests for management of acute clinical Escherichia coli mastitis in crossbred cow. J Livest Sci 7: 41-45

29. Corvec S, Tafin UF, Betrisey B, Borens O \& Trampuz A (2013). Activities offosfomycin, Tigecycline, Colistin and
Gentamicin against extended-spectrum$\beta$-lactamase-producing Escherichia coli in a foreign-body infection model. Antim agents \& chemo 57(3): 1421-1427.

30. Verma H, Rawat S, Sharma N, Jaiswal V \& Singh R (2018). Prevalence, bacterial etiology and antibiotic susceptibility pattern of bovine mastitis in Meerut. $J$ Entom Zool Stud 6(1): 706-709.

31. Habeeb F, Shakir E, Bradbury F, Cameron P, Taravati MR, Drummond AJ, Gray AI \& Ferro VA (2007). Screening methods used to determine the anti-microbial properties of Aloe Vera inner gel. Methods 42: 315-320. 